\section{SOI: $1.1 /$ TAS DOI: $10.15863 /$ TAS International Scientific Journal Theoretical \& Applied Science}

p-ISSN: 2308-4944 (print) e-ISSN: 2409-0085 (online)

Year: $2018 \quad$ Issue: $03 \quad$ Volume: 59

Published: $20.03 .2018 \quad$ http://T-Science.org
Vasila Karimbekovna Abdullaeva

Doctor of sciences in medicine,

Head of Department of psychiatry and medical psychology

Tashkent pediatric medical institute, Uzbekistan

Sherzad Tairovich Tuychiev

Assistant of Department of psychiatry and medical psychology

Tashkent pediatric medical institute, Uzbekistan

\title{
PSYCHOLOGICAL FEATURES OF THE PERSONALITY OF PATIENTS WITH ALCOHOL ADDICTION
}

\author{
Abstract: On the basis of the complex analysis of personality peculiarities of patients with alcohol addiction \\ significant diagnostic psychological markers are determined, which allow predicting the duration of therapeutic \\ remission and the degree of rehabilitation resource. A certain set of motivational, characterological and \\ individual-typological features of the personality of patients with alcohol addiction affect the effectiveness of \\ therapeutic remission. \\ Key words: alcohol addiction, psychological features, personality \\ Language: English \\ Citation: Abdullaeva VK, Tuychiev ST (2018) PSYCHOLOGICAL FEATURES OF THE PERSONALITY \\ OF PATIENTS WITH ALCOHOL ADDICTION. ISJ Theoretical \& Applied Science, 03 (59): 144-146. \\ Soi: http://s-o-i.org/1.1/TAS-03-59-23 Doi: crossef https://dx.doi.org/10.15863/TAS.2018.03.59.23
}

\section{Introduction}

The medico-social significance of the problem is determined, first of all, by the high prevalence of alcohol consumption and its harmful effects on the health of the population. The structure of addiction is still dominated by alcohol disorders [1, p. 90]. Most modern researchers of alcohol addiction believe that the main role in the development of chronic alcoholism belongs to microsocial factors, but the effect of which is mediated by the personality of the patient, his reactions to favorable and negative social impacts [2, p. 74].

In this regard, the analysis of the dependence of the effectiveness of the treatment of chronic alcoholism on the peculiarities of the personal sphere of patients is important not only for the study of the clinic and the pathogenesis of the disease [3, p. 308], but also is of independent interest for the theoretical development of personality psychology [4, p. 182]. It should be noted that the ideas about the structure of personal changes in patients with chronic alcoholism are not holistic, unambiguous, systematized and, accordingly, need further study [5, p. 90].

First of all, we are talking about the study of the role of motivational entities in the formation and course of the disease [6, p. 10], which is important for understanding its clinic and pathogenesis and opens up new opportunities for improving the system of treatment and rehabilitation of patients with chronic alcoholism [7, p. 606]. Many biological, psychological and social factors play a role in the emergence and development of chronic alcoholism [8, p. 62]. In this case, the personal characteristics of patients remain significant at any stage of the course of the disease: in the initial period, the developed stage or in the period of relative well-being and arise as a result of treatment or for any other reason $[9, \mathrm{p}$. $118]$.

At the same time, psychological factors closely related to the personal characteristics of the individual can contribute to favorable results of treatment, a relatively benign course of the disease and prevent the desired results of therapy, reducing its effectiveness, contribute to the weighting of the painful process $[10$, p. 356]. This necessitates a careful study of the individual characteristics of each patient and determine their role during the disease in order to in one case use them as a tool in the rehabilitation process, and in the other to carry out their appropriate correction to avoid failure in treatment and recovery activities [11, p. 120].

The aim of the study was to study the motivational, individual-typological and characterological characteristics of the personality of patients with alcohol addiction and their relationship with the duration of therapeutic remission.

\section{Material and methods:}

The psychological examination of 57 patients with alcohol addiction who underwent inpatient 
treatment in the Republican Narcology Center of Uzbekistan was conducted in the course of the study. Methods of clinical diagnosis (observation, conversation, analysis of life history and disease), which contributed to the establishment of contact and collection of history, became research methods. Of psychometric techniques were used: a questionnaire of motives of alcohol consumption and abstinence from alcohol consumption is to identify the dominant motives of consumption and abstinence from alcohol consumption, test to evaluate therapeutic units to diagnose the severity of installations for the treatment, sobriety and life goals, the questionnaire Smisek-Leonhard, a standardized multi-factor method of personality research is to identify individual-typological peculiarities of the personality of patients with chronic alcoholism, the test Rokich to identify the main life goals and means of achieving these goals.

\section{Results and discussion:}

We have undertaken research of personal features of patients with chronic alcoholism and their interrelation with duration of therapeutic remission. We proceeded from the fact that the analysis of the identity of the personal characteristics of patients with chronic alcoholism will lead to a more adequate understanding of the psychological mechanisms of personality functioning in this population of patients that will later serve as a justification for a differential approach to psychotherapy with these patients. During the study, we found that many patients are psychologically not ready for treatment, i.e. to the process of changing their behavior - the transition from alcohol intake to cessation. Therefore, before the use of special treatments, it is necessary to prepare the patient for the process of changing their own lifestyle. Our study showed that persons with prior consultation in the form of psychological research and motivational interviewing, addiction treatment is much more successful than those who once were included in the treatment program. The results of the study significantly expand the existing traditional ideas about the personal characteristics of patients with chronic alcoholism and indications for short-term methods of psychotherapy.

In the structure of motivation of alcohol consumption in patients who fail to comply with the regime of sobriety, dominated by socio-traditional and hedonic motives. The motives of the pathological group (hangover and additive) and ataractic motives are presented slightly. In patients with chronic alcoholism, admitting "setbacks" in the first year of remission, it was observed the dominance of ergopathic, sensitive and harmonious types of attitude to disease. In patients with the leading disturbing type of the relation to alcoholism and type of reaction with an intrapsychic orientation of violations of the mode of sobriety it wasn't noted.
The greatest number of remission disorders was revealed in patients with chronic alcoholism with pronounced emotional lability, prone to neurotic protective reactions of conversion type and rigidity, manifested by a subjective logical scheme, often unsuitable for external correction. Insufficient duration of therapeutic remission is observed in patients with chronic alcoholism with an external variant of the total therapeutic settings manifested in cognitive, affective and behavioral spheres.

The main individual-typological and characterological features of the personality, increasing the duration of therapeutic remission are: age-31-40 years; the presence of 1-2 or 2 stages of chronic alcoholism; in the structure of the motivation of alcohol consumption predominate ataractic and actually pathological motives; the prevailing tone of the sympathetic nervous system; dominated by an alarming type of attitude to the disease; expressed internal and intermediate settings for treatment, sobriety and target settings; balance of personal qualities; the presence of a stress component during the examination; the presence of signs of asthenization; sufficient reliability of the examination; changes in physiological parameters during the psychological examination.

Quantitative analysis of the questionnaires for the study of the personal characteristics consisted in counting the points for each test, determining the percentage of subjects with accentuation in the group of subjects with alcohol addiction. We have identified that for individuals suffering from alcohol dependence, is characterized by such accentuation, as turned, anxiety and cyclothyme. Thus, it can be said that alcoholism, on the one hand, contributes to the sharpening of such traits that form the basis of these accents, and, on the other hand, for people prone to alcohol dependence, characterized by such traits as lack of discipline, striving for leadership and domination by any means; increased anxiety, low self-esteem, the desire to avoid responsibility, a high motive for avoiding failure, the dominance of psychological protection mechanisms by the type of avoidance; sharp mood swings, a tendency to autoagression.

It should be noted that among persons suffering from alcohol addiction, there are people with other accentuations of character: exaltation, disciminate, ostentation, pedantry, emotively, jam.

The main individual and psychological parameters of the personality of patients with chronic alcoholism, having a stable remission for more than three years are: the presence of a strong sober attitude and position, acquired the skills of a healthy lifestyle, formed a sober outlook. The main motive of the activity-maintaining the position and achieving success; social readaptation (preservation of family relations, employment). The following prevails: the leading emotion stability, and position in life - 
mature, courageous, the basic type of response - a strong, characteristic resistance, persistence, leadership, desire for self-assertion, stability, emotional state, the absence of severe anxiety; signs of psychological addiction to alcohol desactualized; in the structure of motivation for abstinence of alcohol consumption is dominated by motives associated with health and lack of psychological addiction to alcohol.

\section{Conclusions:}

Thus, on the basis of a comprehensive analysis of the personality characteristics of patients with alcohol addiction, significant diagnostic psychological markers are determined that allow predicting the duration of therapeutic remission and the degree of rehabilitation resource. A certain set of motivational, characterological and individualtypological features of the personality of patients with alcohol addiction affect the effectiveness of therapeutic remission.

Psychological features of the personality of patients with alcohol dependence characterize the level of readaptation, which is a criterion for the effectiveness of psychotherapeutic treatment. An intensive psychological correction, built taking into account personal characteristics of patients and clinical disease, is essential to achieve a positive therapeutic dynamics.

\section{References:}

1. Zaysev SN (2004) Sozavisimost - umenie lyubit // Posobie dlya rodnyh i blizkih narkomana, alkogolika, p. 90.

2. Zorina LM (2006) Sozavisimost i puti yeyo preodoleniya // Upr. Feder. slujby RF po kontrolyu za oborotom narkotikov po RT. Vol. 2, p.74.

3. Emelyanova EV (2010) Krizis v sozavisimyh otnosheniyah. Prinsipy i algoritmy konsultirovaniya. p. 368.

4. Moskalenko VD (2002) Psihicheskaya predraspolojennost $\mathrm{k}$ razvitiyu zavisimosti ot PAV (lichnostnye, sotsialnye, semeynye faktory riska) // Rukovodstvo po narkologii Vol 1, pp. 182-188.

5. Nagornova AYu (2004) Tehnologiya sosialnoy raboty s semyami alkogolikov // Ulyanovsk: UlGPU, p. 90.

6. Tiffany ST, Wray JM (2012) The clinical significance of drug craving. // Ann NY Acad Sci pp.1-17.

7. Skinner MD, Aubin HJ (2010) Craving's place in addiction theory: contributions of the major models // Neurosci Biobehav Rev 34, pp. 606623.

8. Fatseas M, Auriacombe M (2009) Principes de la thérapeutique et des prises en charge en addictologie // Fundamentals \& Addiction Treatment In: M. Lejoyeux, editor. Abrégé d'Addictologie. pp. 62-69.

9. Serre F, Fatseas M, Debrabant R et al. (2012) Ecological momentary assessment in alcohol, tobacco, cannabis and opiate dependence: a comparison of feasibility and validity. // Drug Alcohol Depend Vol. 126, pp. 118-123.

10. Denis C, Fatseas M, Beltran V et al. (2012) Validity of the Self Reported Drug Use Section of the Addiction Severity Index and associated factors used under naturalistic conditions // Subst Use Misuse, Vol. 47, pp. 356-363.

11. Flannery BA, Poole SA, Gallop RJ, Volpicelli JR (2003) Alcohol craving predicts drinking during treatment: an analysis of three assessment instruments // J Stud Alcohol, Vol. 64, pp. $120-126$. 